Original Paper

doi $10.15826 /$ recon.2020.6.2.008

\title{
Strategic priorities for the development of middle regions in Russia
}

\author{
V.V. Akberdina $₫$, A.S. Sergeeva \\ Institute of Economics of the Ural Branch of the Russian Academy of Sciences, Ekaterinburg, Russia; \\ e-mail:akb_vic@mail.ru
}

\begin{abstract}
Relevance. The key factor in the development of any region is its geographical position in the socio-economic and geopolitical space of the country. In this respect, middle regions are of particular interest. Unfortunately, their unique qualities remain largely underexplored in research literature, which is the gap this article seeks to address. Research objective. The purpose of the study is to provide a definition of the concept 'middle region', describe its key characteristics and align them with the strategic priorities in the development of such regions. Data and methods. The research methodology centres around the notion of cumulative effect of the middle region and the tools for its assessment. This effect is associated with enhanced socio-economic efficiency of a territorial capital resulting from the advantages of its middle position. Among other things, this effect manifests itself through higher economic returns on investment. The empirical part of the study relies on the data on 36 Russian middle regions, their missions and priorities of strategic development. Results. The article summarizes the Russian and international theoretical approaches to the definition of the middle regions, their place and role in the territorial structure of a country and its socio-economic development. It is shown that most authors assign middle regions the role of the country's epicenter, highlighting their key role in economy, culture, politics and other spheres of life. The approach proposed in this study focuses on middle regions' position in space, on the one hand, and, on the other, sees them as systems of interactions in the socio-economic space. Based on this understanding of the middle region, several groups of Russian middle regions are identified: integrators, sustainable middle regions and developing middle regions. Conclusions. The mission of middle regions is one of the fundamental concepts of strategic management, comprising a hierarchy of goals. It is shown that although the mission of middle regions should be to become integrators of the country's socio-economic space through the network of inter-territorial and global interactions, not all Russian middle regions are ready to pursue this ambitious goal and prefer to focus on addressing internal goals of their own.
\end{abstract}

\section{KEYWORDS}

middle regions, strategic priorities, mission, economic and geographical position, resonant effect

\section{ACKNOWLEDGEMENTS}

The research was supported by the Institute of Economics of the Ural Branch of the Russian Academy of Sciences (research plan for 2019-2021).

\section{FOR CITATION}

Akberdina, V.V., \& Sergeeva, A.S. (2020) Strategic priorities for the development of middle regions in Russia. R-economy, 6(2), 89-99. doi: $10.15826 /$ recon.2020.6.2.008

\section{Стратегические приоритеты развития срединных регионов России}

\author{
В.В. Акбердина $₫$, А.С. Сергеева \\ Институт экономики Уральского отделения Российской академии наук, г. Екатеринбург, Россия; \\ e-mail:akb_vic@mail.ru
}

\section{АННОТАЦИЯ}

Актуальность. Ключевым фактором развития любого региона является его географическое положение в социально-экономическом и геополитическом пространстве страны. Среди различных типов пространственных позиций региона по отношению к его стране значимо выделяются срединные регионы. Цель исследования. Целью исследования является формулировка подхода к идентификации срединных регионов и обоснованию стратегических приоритетов их развития. Данные и методы. Методология исследования сосредоточена вокруг понятия «кумулятивного срединного эффекта» и предлагают методический инструментарий его оценки. Данный эффект представляет собой превышение ключевых социально-экономических показателей срединного региона над среднероссийскими показателями. Помимо прочего, этот эффект проявляется через более высокую экономическую отдачу от инвестиций. Для проведения эмпирического исследования были отобраны 36 регионов Российской Федерации. Все они (๔) Akberdina, V.V., Sergeeva, A.S., 2020

\section{КЛЮЧЕВЫЕ СЛОВА}

срединные регионы; стратегические приоритеты; миссия; экономикогеографическое положение, резонансный эффект 
классифицируются по географическому положению как средние регионы. Результаты. В статье обобщены теоретические подходы российских и зарубежных ученых к определению срединных регионов, их месту и роли в территориальном устройстве страны и ее социально-экономическом развитии. Показано, что большинство авторов отводят срединным регионам роль главного эпицентра страны, выделяют его решающее участие в делах государства, сохраняющуюся за ним ключевую роль в экономике, культуре, политике и других сферах жизни. Подход, предложенный в этом исследовании, фокусируется на положении срединных регионов в пространстве, с одной стороны, и, с другой стороны, рассматривает их через систему взаимодействий в социально-экономическом пространстве. Проведенное исследование позволило авторам выделить такие типы средних регионов, как «интегратор экономического пространства», «устойчивый средний регион» и «развивающийся средний регион». Выводы. Миссия срединных регионов - одна из фундаментальных концепций стратегического управления, и она включает в себя иерархию целей. Показано, что, хотя миссия средних регионов должна состоять в том, чтобы стать интеграторами социально-экономического пространства страны через сеть межтерриториальных и глобальных взаимодействий, не все средние российские регионы готовы преследовать эту амбициозную цель и предпочитают сосредоточиться на решение внутренних задач самостоятельно.

\section{БЛАГОДАРНОСТИ}

Работа выполнена при поддержке Института экономики Уральского отделения Российской академии наук (план исследований на 2019-2021 гг.).

\section{ДЛЯ ЦИТИРОВАНИЯ}

Akberdina, V.V., \& Sergeeva, A.S. (2020) Strategic priorities for the development of middle regions in Russia. R-economy, 6(2), 89-99. doi: $10.15826 /$ recon.2020.6.2.008

\section{Introduction}

The location of a region in socio-economic and geopolitical space is a crucial factor of its development. Rodoman (2012) defines spatial position as 'a set of spatial aspects characterizing the relationship of an object to other objects that are essential for the object in question' and proves that the properties of objects depend on their position in space. He refers to this set of spatial aspects as the 'pressure of the place' or 'positional pressure'.

The position of an object in space is not only its 'absolute' position in the geographical system of coordinates but also its position in relation to other objects. In addition, the position of an object in space must be considered and determined within the system of time coordinates.

Although one can speak of an object's position in space from different perspectives, such as physical-geographical, political-geographical, cultural-geographical, geopolitical, and so on, the economic-geographical position (EGP) is by far the most significant. According to Gritsay et al. (2002), the EGP can be considered not only as a factor, but also as 'an important territorial resource that mediates the role of external resources for this object and affects its development along with its own natural and labor resources, as well as scientific and technical potential. Pilyasov (2011) analyzes the EGP as a 'special kind of asset.' Some studies place a special emphasis on innovation, i.e. the position of an object in relation to the ways of spreading new knowledge and processes (innovation) of different significance and scale (Bulaev \& Novikov, 2011; Leizerovich, 2006).
The concept of economic-geographical position is inextricably linked to the concept of economic space, which, on the one hand, is a combination of the territory where economic entities are located and their interactions and, on the other hand, the socio-economic environment where these interactions take place, formed by mechanisms of economic regulation in the given territory. It should be noted that economic space usually comprises such elements as economic entities; relations and interactions between them; regulatory mechanisms determined by the institutional conditions within the territory (norms and rules for regulating relations) (Baldwin et al., 2003; Bathelt \& Glückler, 2003; Тота et al., 2014).

A region can occupy various spatial positions within the country, for example, it can be located in the middle and in this case, it can be referred to as a middle region. The middle region, due to its location, accumulates many functions: production, social, political, and other. The purpose of the $s t u d y$ is to describe an approach that can be used to identify middle regions and determine strategic priorities of their development. Our study will consider the topological features of middle regions, the effects their position within the country has on their development and their mission in the overall development of the country.

Our research contributes to the theory of regional economics by clarifying the concept 'middle region', describing its topological features, and highlighting its mission. The proposed methodology can be of use to regional and federal authori- 
ties when developing, adjusting and updating spatial development strategies.

\section{Conceptual framework}

To understand what distinguishes the middle region as a separate type of regions, it is necessary to look at other types or classes of regions. According to Gladkiy \& Chistobaev (2011), more than 50 categories of regions are identified in research literature. We are going to focus only on the most relevant typologies of regions, for example, the distinctions between central and peripheral regions or such types as coastal regions, border regions and remote regions (Golubev, 2011).

The concept of middle region is closely connected to that of a 'central' region. It should be noted that 'center' and 'middle' are not synonymous from the perspective of regional economy and economic geography. In the classical sense, these two words have a very close meaning: the center is the middle and main part of something; the core, the place of concentration of something. Both notions have been established in regional economics and geography. The term 'central' is closer in its meaning to the concept of 'capital' than to 'middle'. In the concept 'middle region', one can more clearly trace its main distinctive feature - territorial location in the middle of a country, continent, part of the world or another larger spatial unit.

The term 'center' as well as other related structural taxonomic elements is defined by Alaev (2010) in socio-economic dictionary the following way: the 'center' is a point (a geographical object or section) whose connections with the surrounding area are functional. The center that distributes flows of matter, energy, and information to the surrounding landscape and generally transmits its characteristics to the landscape should be called the focus (or center of diffusion, distribution); the center towards which there is a contraction, concentration of matter and energy - the focus (or center of attraction). According to Alaev (2010), the concepts 'center', 'focus', and 'core' suggest the presence of an opposing, complementary taxon territory, which in this case is called the periphery.

The concepts of centrality and middle play an important role in many theories of production organization (Losch, 1944; Weber, 1909; Christaller, 1933; Isard, 1960; Krugman, 1991; Lukermann, 1960). However, middle regions differ from central ones (although theoretically they may coin- cide) because the former are not necessarily located in the historical center of the country and are not always endowed with all the high capital functions, including administrative and managerial ones.

The middle region is a region that is located in the middle of a higher-order territory (country, part of the world, continent, or other larger space). The most important distinctive quality of such a region is that the average distance of movement from this region to any point of the "mother" territory, of which it is a part, will be less than the same average distance to any point of this territory in other regions' (Tatarkin, 2005). The middle region is more accessible to other regions, and other regions are easier accessed from the middle.

The contemporary research literature devoted to spatial organization of production and regions of different types highlights the unique economic features and geographical location of all middle (and central) regions, in particular the phenomenon of the middle, which acts as a catalyst for regional development. The concept of the median can be considered at different spatial scales a single country or group of counties, a largerscale region, city, i.e. a middle region can be seen not only as a part of the country but can also be a country itself. We will be more interested in middle regions located within one country. In this respect, the studies of the Ural scientific school (A.Tatarkin, E. Animitsa, E. Dvoryadkina, N. Novikova, Yu. Lavrikova, A. Glumov and others) are of particular interest (Animitsa et al., 2008).

The middle region has many functions that are connected to its location. What is important is not only a certain number of roads or highways, but also the benefits that the region receives due to its position at the intersection of the most important transport routes, which, in its turn, has an impact on its economic development.

First of all, the development of transport and logistics and tax revenues from companies operating in the transport services market guarantee new jobs and, of course, investment in the development of transport and logistics infrastructure and other spheres. Such economic and geographical location also favours the development of trade and business infrastructure (restaurants, hotels, warehouses, shopping and business centers, offices of global companies, etc.), since it is convenient to hold exhibitions and meetings and to open branches and offices in middle regions. 
Another advantage of such location is the development of production functions since it allows enterprises to save on transportation of raw materials and products across the region or to its borders. The concentration of production depends on how actively and effectively the region uses local natural resources and technological achievements. Position in the middle makes such regions better protected against 'unfriendly' penetration. Therefore, these regions often host strategically important facilities for the country - defense enterprises, nuclear power plants, etc.

The development and expansion of managerial and organizing functions in the middle region (industrial, social, political, and other) is an important sign of the middle region. Various organizational and managerial entities operating in the region contribute to the increasing uniformity and integration of the regional economic space; implement their own regional strategic projects; initiate interactions between economic entities; accelerate decision-making in the economic sphere, thereby helping economic entities to save on transaction costs.

One of the key features of the middle region is its participation in state affairs and its role in the economy, culture, politics and other spheres of life.

Middle regions are often characterized by their own, unique processes of formation and development in different countries. These characteristics are rooted in these regions' individual history and create a specific socio-economic environment, certain demographic commonality, necessary for the regions' development through the effective use of natural, economic, social, demographic, and other innovative capabilities and engagement of all internal forces. Since the unique characteristics of a middle region to a great extent originate in its history, it is necessary to emphasize the role of the time factor, i.e. implementation and maintenance of the middle region's functions over a long historical period. The region for many decades and even centuries (the latter is especially typical of Russian regions) accumulates traditions, forms a multi-layered economy, developed infrastructure, while remaining in the thick of national events.

E. Animitsa defines the middle region as a special, state-forming type of a large region which is located in the central, strategically important part of the country and has a set of specific topological features such as a significant number of 'entrances' and 'exits' to passenger and cargo flows, a high level of concentration of production and population, scientific and technical, intellectual and human potential, historically formed infrastructure, industrial and technological and socio-cultural connectivity, and regional identity. Moreover, such regions have a powerful core (or several cores), that is, the largest cities that have the official status of administrative, political, economic, organizational centers of their respective territories. A. Glumov's approach is similar to that of E. Animitsa, but it focuses on the concentration of the country's population, production, capital and resources in middle regions (Animitsa \& Glumov, 2007).

Tatarkin (2005) interprets the middle region as being located in the middle of the territory of a country, continent, part of the world or other, larger units. In our opinion, these definitions fail to emphasize the role of the middle region as an integrator of space, its special geopolitical, socio-economic, cultural and spiritual mission. The functional features of any middle region can be determined by forecasting the economic effect of its development.

Taking into account the conceptual characteristics discussed above (central location, developed transport and business infrastructure, concentration of population, industry and other sectors), it is also necessary to highlight a number of topological qualities (properties) that distinguish this type of regions. These are objectivity, multi-dimensionality, scale, which determines their role in the development of the country, openness, contacts with other regions, transit potential, attractiveness for capital and people. In addition, it should be noted that middle regions play an important creative and integrative role in the sphere of production, financial, social and business spheres, in maintaining the interconnectedness of regions, in the formation of a single economic and political space of the country.

Thus, the middle region can be defined through its territorial position, on the one hand, and through its connection to the system of interactions in the socio-economic space of the state, on the other. The middle region is understood here as a complex hierarchical system in the multi-level territorial structure of the country, whose unique features are determined both by its central geographical position and the set of relationships and dependencies arising as a result of 
the region's strategically important role in national socio-economic development and security.

It should be emphasized that the distinctive features of such understanding of the middle region is, firstly, the rejection of the idea of equidistance from the geographical borders of the state, and secondly, the disclosure of the median factor not only through geographical location, but also through the totality of relations between economic entities, integrated structures and authorities at various levels. Our understanding of the middle is directly related to the etymology of this word, namely, being in the middle of something or between two objects. This is what distinguishes this concept from the concept of geographical center, which is equidistant from the borders. Thus, our approach relies on the definition of the middle region is a set of features, connections and relations and the more general notion of region as a relatively stable part of the socio-economic and political space of the country.

There can be several middle regions in a country. The middle region as an integral system of interactions and interdependencies that, on the one hand, provide connectivity within the region and, on the other, make it to the outside world. From the morphological point of view, one of the key characteristics of the middle region is its 'polystructuredness', which is a specific feature of the Russian space, where administrative and political centers appear to be superior in status to their territories.
As Table 1 illustrates, we supplemented the topological features that are traditionally emphasized in the definitions of the middle region such as spatial location, administrative component, socio-economic component, and interactions with some new ones.

\section{Methodology and Data}

The methodological framework of our study centres around the concept of cumulative effect and comprise tools for its assessment. The cumulative effect of the middle region, in our view, is created by its unique topological features, advantages and disadvantages of its geographical position. The cumulative effect of the middle region is understood here as the socio-economic efficiency of a territorial capital resulting from the advantages of its middle position. The cumulative effect leads to the region's enhanced socio-economic performance in comparison with the national average, in particular a high economic return on investment (Hanson, 2005; Oerlemans, 2001; Head, 2010). In this regard, to estimate the cumulative effect, we need to look at the indicators corresponding to such spheres as economy, regional budget, innovation, industry, trade, construction, transport, and social sphere (education and health).

The methodology for calculating the cumulative effect of the middle region comprises a system of indicators and a procedure for their integration. The most successful way to assess the cumulative

Table 1

Topological features of middle regions

\begin{tabular}{|c|c|c|c|}
\hline & $\begin{array}{c}\text { Classification } \\
\text { group of features }\end{array}$ & Traditional features & Additional features \\
\hline \multirow[t]{2}{*}{ Territory } & Spatial & $\begin{array}{l}\text { Scale } \\
\text { Location in the 'middle' } \\
\text { Transitivity } \\
\text { Historical infrastructure } \\
\text { Cargo and passenger traffic }\end{array}$ & $\begin{array}{l}\text { Resources } \\
\text { Gravity }\end{array}$ \\
\hline & Administrative & $\begin{array}{l}\text { Openness } \\
\text { Population concentration } \\
\text { One core or multiple cores } \\
\text { Regional identity }\end{array}$ & $\begin{array}{l}\text { Polystructuredness } \\
\text { Role in ensuring national security } \\
\text { Territorial 'frame' (P. George's term) } \\
\text { Financial self-sufficiency } \\
\text { Multiple pilot projects }\end{array}$ \\
\hline \multirow[t]{2}{*}{ Relationships } & $\begin{array}{l}\text { Socio-economic } \\
\text { component }\end{array}$ & $\begin{array}{l}\text { Multidimensionality } \\
\text { Play a defining role in the national economy } \\
\text { Concentration of industries, trade and services } \\
\text { Concentration of intellectual and human potential }\end{array}$ & $\begin{array}{l}\text { Low risk of doing business } \\
\text { High investment and innovation } \\
\text { potential } \\
\text { Investment climate }\end{array}$ \\
\hline & Interactions & $\begin{array}{l}\text { Multiple contacts with neighboring territories } \\
\text { Attractiveness for capital and people } \\
\text { Connectedness }\end{array}$ & $\begin{array}{l}\text { Space integration } \\
\text { Interrelated regional development } \\
\text { Resonance effect } \\
\text { Network interactions } \\
\text { Clustering }\end{array}$ \\
\hline
\end{tabular}


effect is to determine the value of the integral index. In doing so, we can, for example, rank the regions under consideration based on individual indicators and integrated assessment; such ranking can be easily updated by using the current values of indicators for calculations. In addition, the methodology has significant potential for scaling - it can be applied to an increasing number of research objects (for example, countries) without extra adjustment.

It is important to identify the indicators that characterize the metrics of the region's middle position. The choice of the indicators that should be taken into account in the calculation process largely depends on the researchers' goals, their expertise, and the availability of information that can be used in the calculations. Special attention, as it was noted earlier, should be paid to the reliability of the proposed indicators as well as the access to the necessary data. The data about the development of territories and industries can be obtained from official government statistics; corporate reports; surveys and research conducted by private companies.
It is very important at this stage to check the tightness of the regression relationship between the selected indicators: if any indicators related to the same area closely correlate with each other, it is necessary to exclude one (or more) of them from the set of indicators used in the analysis.

To calculate the cumulative effect, we are going to use the power function from the product of partial indicators of the effects of the middle position of the regions (Table 2):

$$
R_{M P}=\sqrt[n]{\prod_{i=1}^{n} R_{i}},
$$

$R_{M P}$ is the cumulative effect of the region's middle position and $R_{i}$ signifies the effects that occur in certain areas (Table 2 ).

To conduct an empirical study, we selected 36 Russian regions classified as middle regions. These regions are homes to $43.7 \%$ of the country's population. They also account for $38.9 \%$ of Russia's GDP; $64.2 \%$ of the volume of mineral production; $41.5 \%$ of investment in fixed assets; and $44.7 \%$ of the volume of innovative production.

Indicators for calculating the cumulative effect of the region's middle position

\begin{tabular}{|c|c|c|c|}
\hline $\mathbf{N}$ & $\begin{array}{l}\text { Effects by } \\
\text { location }\end{array}$ & Key indicator & Formula for calculating the effect \\
\hline$R_{1}$ & Economy & $\begin{array}{l}\text { Value added per } 1 \text { unit } \\
\text { of investment }\end{array}$ & $\frac{\mathrm{GRP} / \text { Investment in the region }}{\mathrm{GDP} / \text { Investment in the country }} \cdot 100 \%$ \\
\hline$R_{2}$ & Budget & $\begin{array}{l}\text { Regional budget per } 1 \\
\text { unit of investment }\end{array}$ & $\frac{\text { Consolidated budget/Investment in the region }}{\text { Country budget/Investment in the country }} \cdot 100 \%$ \\
\hline$R_{3}$ & Innovation & $\begin{array}{l}\text { Volume of innovative } \\
\text { products per } 1 \text { unit of } \\
\text { investment }\end{array}$ & $\frac{\text { Innovative products of the region/Investment in the region }}{\text { Innovative products in the country/Investment in the country }} \cdot 100 \%$ \\
\hline$R_{4}$ & Industry & $\begin{array}{l}\text { Added value in industry } \\
\text { per } 1 \text { unit of investment }\end{array}$ & $\frac{\text { Added value in Industry of the region/Investment in the region }}{\text { Added value in Industry in the country/Investment in the country }} \cdot 100 \%$ \\
\hline$R_{5}$ & Trade & $\begin{array}{l}\text { Added value of trade per } \\
1 \text { unit of investment }\end{array}$ & $\frac{\text { Added value in Trade of the region/Investment in the region }}{\text { Added value in Trade in the country/Investment in the country }} \cdot 100 \%$ \\
\hline$R_{6}$ & Construction & $\begin{array}{l}\text { Added value in con- } \\
\text { struction per } 1 \text { unit of } \\
\text { investment }\end{array}$ & $\frac{\text { Added value in Construction of the region/Investment in the region }}{\text { Added value in Construction in the country/Investment in the country }} \cdot 100 \%$ \\
\hline$R_{7}$ & Transport & $\begin{array}{l}\text { Added value in transport } \\
\text { per } 1 \text { investment unit }\end{array}$ & $\frac{\text { Added value in Transport of the region/Investment in the region }}{\text { Added value in Transport in the country/Investment in the country }} \cdot 100 \%$ \\
\hline$R_{8}$ & Health care & $\begin{array}{l}\text { Added value in health- } \\
\text { care per } 1 \text { unit of invest- } \\
\text { ment }\end{array}$ & $\frac{\text { Added value in Healthcare of the region/Investment in the region }}{\text { Added value in Healthcare in the country/Investment in the country }} \cdot 100 \%$ \\
\hline$R_{9}$ & Education & $\begin{array}{l}\text { Added value in edu- } \\
\text { cation per } 1 \text { unit of } \\
\text { investment }\end{array}$ & $\frac{\text { Added value in Education of the region/Investment in the region }}{\text { Added value in Education in the country/Investment in the country }} \cdot 100 \%$ \\
\hline
\end{tabular}




\section{Results and discussion}

Our study has showed that the cumulative effect differs significantly across Russian middle regions. Therefore, it seems reasonable to distinguish between such types of middle regions as an 'integrator of economic space', 'sustainable middle region' and 'developing middle region'.

Middle regions of the first type - integrators have the following quantitative characteristics: a high value of the cumulative effect of the middle position; high turnover; high value of gravity on interregional trade; a high proportion of neighboring territories in the balance of interregional trade; and a high coefficient of clustering. Based on the above-described methodology, the following territories of Russia can be described as 'integrator regions': Moscow, Tatarstan, Bashkortostan and Komi republics, Sverdlovsk and Tomsk regions. These regions have a cumulative effect value of more than $150 \%$.

A stable middle region is characterized by a high value of the cumulative effect of the middle; a significant role in the country's overall economic performance; considerable potential for investment and innovation; substantial budget capacity; low risks for doing business; and a large number of national 'pilot projects' operating in their areas. Based on the authors' calculations, this group of regions includes Moscow, Novgorod, Lipetsk, Irkutsk, Vologda, Nizhny Novgorod, Kaluga, Ryazan, Samara and Yaroslavl regions, Perm region, Khanty-Mansiysk Autonomous District and the Udmurt Republic. The value of the cumulative median effect is between 101.6 and $148.2 \%$.

The second type - developing middle region - is characterized by low values of the cumulative effect of the middle; lower levels of investment, innovation and budget capacity; and high risks of doing business. These regions in the short term can potentially move into the category of 'sustainable middle regions', and in the long-term, 'integrators'. This group includes the following regions: Vladimir, Kostroma, Tula, Oryol, Tambov, Tver, Kemerovo, Penza, Ulyanovsk, Kirov and Ivanovo regions, Khakassia, Mari El, Mordovia, Chuvashia, Adygea republics, and Stavropol region. The value of the cumulative middle effect is between 62.1 and $98.9 \%$.

The assessment of the effect of the middle position allowed the authors to test their hypothesis about the special mission of the middle regions.

In the context of globalization and global competition (Wang, 2020), regions become more oriented towards strategic management, which includes the mission of the region, scenarios and concepts of development (Barnes, 2003; Combes

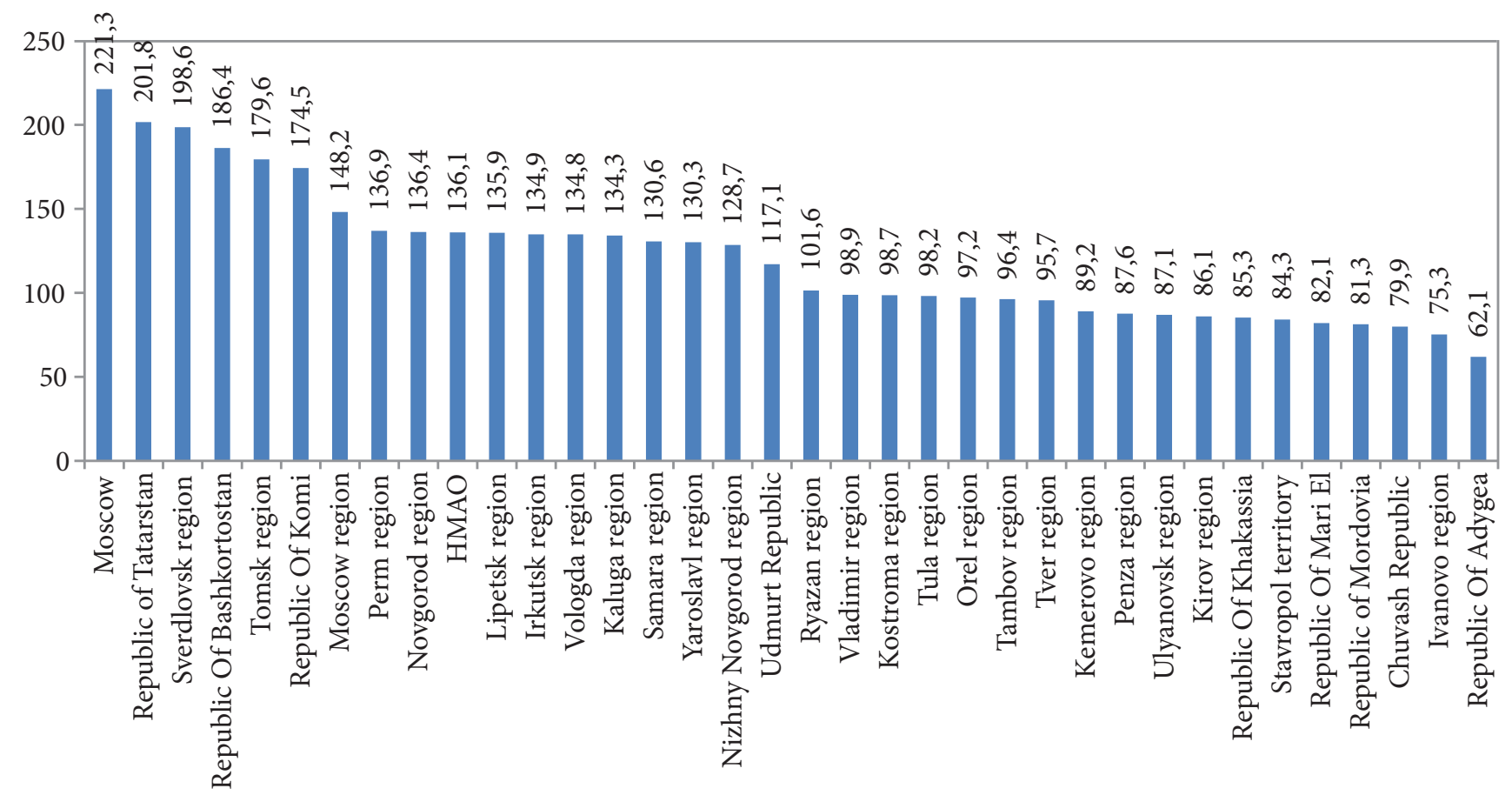

Figure 1. Value of the cumulative middle position effect of Russian regions

Source: the authors' calculations based on data from the statistical yearbook 'Regions of Russia published by the Federal State Statistics Service (Rosstat) https://www.gks.ru/folder/210/document/13204 (Accessed data: March 25th, 2020) 
et al., 2008; Cairncross, 2001), socio-economic forecasting (Zhao \& Fan, 2019; Chen, 2020), targeted integrated programs, and mechanisms for implementing the goals of regional strategic management (Wiberg, 2019; Chen, 2019; Qiu et al, 2020). The mission of the region is one of the fundamental concepts of strategic management; it should be unique in each case and formulated by taking into account the region's specific characteristics. The scenario of socio-economic development of a region should be aligned with the mission and include the strategic goal and tools for achieving it. The tools for implementing the regional strategy rely on organizational, legal, financial and monitoring mechanisms (Zemtsov \& Baburin, 2016). The organizational mechanism includes a set of strategic development and planning documents; the legal mechanism corresponds to the socio-economic sphere, business activities, strategic planning system, etc.; the financial mechanism includes budget strategies, financial plans, etc. The control mechanism is of vital importance; it comprises assessment and expertise, monitoring, etc. Monitoring results help to adjust the short-, medium- and long-term forecasts.

The mission of a region should capitalize on its competitive advantages and helps it survive through the periods of recession by prioritizing certain areas of development. By and large, it could be expected that any middle region should strive to integrate the country's socio-economic space through the network of inter-territorial and global interactions based on the strategic polystructure of the territory and to ensure the socio-economic growth and security of the country.

We analyzed the strategies of 36 middle regions in Russia, paying special attention to their missions, goals and strategic priorities of development. The study showed that not all regions today position themselves as integrators of the country's space. Out of 36 middle regions, only 6 regions, in view of their unique position, connect their missions with spatial development of Russia. In the modern globalized world, success is achieved by those regions that find the right balance between globality and identity, skillfully fitting into the national and world economy, capitalizing on their unique qualities to succeed in interregional competition. Such middle regions include Sverdlovsk, Samara and Tomsk regions, Tatarstan, Komi and Udmurt republics.

Sverdlovsk region defines its mission not only in the national context, but also in the context of global economy, focusing on a new quality of life and new industrialization. The goals of the social and economic policy of Sverdlovsk region for 2016-2030 are enhance its competitiveness in global economy and to improve the quality of life as the region is envisioned to become an attractive territory for human life and development. The strategy highlights three key priorities: 1) in the social sphere, to provide a new quality of life, that is, creation of optimal conditions for accumulation and preservation of human potential; 2 ) in the economic sphere, to promote new industrialization, that is, creation of conditions for increasing the region's industrial, innovative and entrepreneurial potential; and 3) territory for life and business - to ensure balanced development of the region.

The Republic of Tatarstan positions itself as the growth pole of a large region. Its strategy puts forward the main strategic goal: by 2030, to turn Tatarstan into a globally competitive and sustainable region, a driver of the so-called Volga-Kama growth pole. Tatarstan is a leader in terms of the quality of interconnected development of human capital, institutions, infrastructure, economy, external integration ('axial' Eurasian region of Russia) and internal space. It is a rapidly developing region with high involvement in the international division of labor. The strategy centres around three interrelated strategic priorities: 1) formation and accumulation of human capital; 2) creation of a comfortable space for the development of human capital; and 3) creation of economic relations and public institutions for the development of human capital.

Samara region, with its powerful potential, can become a significant point of economic growth in the Volga Federal District. This region holds significant potential for the development of science, education and industry, especially in the aerospace sector and petrochemicals; it is also one of the largest transport and logistics hubs. Its strategic goals of socio-economic development for the period up to 2030 are to ensure economic growth and increase the competitiveness of the regional economy; improve the quality of life; and improve the efficiency of regional management.

The mission of Tomsk region emphasizes a better quality of life in Siberia, which is planned to be achieved by implementing an intensive development model. Priorities of socio-economic development of Tomsk region are the new technologies; human capital; conditions for invest- 
ment and business development; effective territorial policy; and effective management.

The mission of the Republic of Komi emphasizes the region's role in the country's prosperity and prioritizes comfortable conditions for residents and their families, which includes a good living environment, education and health care, opportunities for personal growth and social security. The high quality of life in the region should be based on sustainable economic growth and attraction of investors.

The mission of the Udmurt Republic is to become a developed industrial region supplying high-tech products to national and world markets. The main goal of social and economic development of the Udmurt Republic in the long term is to increase the efficiency and stability of the economy and improve the quality of life.

Unfortunately, the missions of the other middle regions in this group are not so ambitious. Most of the missions largely focus on the regions' internal development, building a sustainable economy, improving the quality of life and addressing the problem of population decline.

\section{Conclusions}

Russia occupies a vast territory with regions as the main structural elements. Among the regions, the middle regions play a significant role they serve as integrators and enhance interactions between the territories through various business, governmental, organizational and managerial structures. The middle region, due to its location, accumulates many industrial, social, political and other functions.

The review of international and Russian research literature on this topic has revealed a certain knowledge gap regarding the theory of development of large middle regions. It was this gap that this article sought to address: we strove to clarify the theoretical and methodological aspects of the concept 'middle region' based on the gravitational theory, cluster theory, and methodology for evaluating innovation potential. In particular, we substantiated the approach that reveals the unique nature of middle regions: focusing on their location and at the same time describing them as systems of interactions in the socio-economic space of the state. We have added some important topological features of the middle region to the already established understanding of this type of region. Our analysis of Russian regions' missions has demonstrated that middle regions can play an important role in ensuring the country's long-term growth and security as integrators of the country's social and economic space through the network of inter-territorial and international connections on the basis of strategic polystructural areas.

The quantitative assessment of the cumulative effect of middle regions can be used in policy making on regional and national levels.

\section{References}

Alaev, E.B. (2010) Socio-economic geography: a conceptual and terminological dictionary. Moscow, 273. (In Russ.)

Animitsa, E.G., Dvoryadkina, E.B., Novikova, N.V., et al. (2008) Region in the socio-economic space of Russia: analysis, dynamics, management mechanism. Perm: PSU, 272. (In Russ.)

Animitsa, E.G., \& Glumov, A.A. (2007) The middle region: theory, methodology, analysis. Yekaterinburg, 296. (In Russ.)

Baldwin, R., Forslid, R., Martin, F., Ottaviano, G., \& Robert-Nicoud, F. (2003) Economic geography and public policy, Princeton University Press, 487.

Barnes, T.J., Peck J., Sheppard, E., \& Tickell A. (2003). Reading economic geography. Oxford: Blackwell, 249.

Bathelt, H., \& Glückler, J. (2003) Toward a relational economic geography. Journal of Economic Geography, 3(2), 117-144.

Bulaev, V M., \& Novikov, A.N. (2011) Geographical position as the subject of research of a specific territory. Ulan-Ude, 315. (In Russ.)

Cairncross, F. (2001). The death of distance: How the communications revolution is changing our lives. Harvard Business Press, 283.

Chen, J. (2019) Geographical scale, industrial diversity, and regional economic stability. Growth and change, 50(2), 609-633. 
Chen, J. (2020) The Impact of Cluster Diversity on Economic Performance in US Metropolitan Statistical Areas. Economic development quarterly, 34(1), 46-63.

Christaller, W. (1933) Die zentralen Orte in Suddentschland. Jena, 244.

Combes, P.P., Mayer, T., \& Thisse, J.T. (2008). Economic geography: the Integration of regions and nations. Princeton: Princeton University Press, 427.

Gladkiy, Yu.N., \& Chistobaev, A.I. (2011) Regional studies. Moscow, 254. (In Russ.)

Golubev, V. (2011) On the question of the economic typology of Russian regions. Science and industry of Russia, 9, 67-74. (In Russ.)

Gritsay, O.V., Ioffe, G.V., \& Treyvish A.I. (2002). The centre and the periphery in regional development. Moscow: Nauka. (In Russ.)

Hanson, G.H. (2005). Market potential, increasing returns and geographic concentration. Journal of international economics, 67(1), 1-24.

Head, K., \& Mayer, T. (2010). Gravity, market potential and economic development. Journal of Economic Geography, 2, 29-37.

Isard, W. (1960) Methods of Regional Analysis; an Introduction to Regional Science. Cambridge: Published jointly by the Technology Press of the Massachusetts Institute of Technology and Wiley, New York, 263.

Keller, W. (2002) Geographic Localization of International Technology Diffusion. The American Economic Review, 92(1), 120-142.

Krugman, P.R. (1991). Geography and Trade. Massachusetts Institute of Technology, Cambridge, 247.

Leizerovich, E.E. Basic components of the economic and geographical position of countries and regions. Izvestiya RAS. Ser. Geography, 1, 25-31. (In Russ.)

Losch, A. (1944) Die raumliche Ordnung der Wirtschaft. Jena, 185.

Lukermann, F., \& Porter, P. (1960) Gravity and potential models in economic geography. Annals of the Association of American Geographers, 50(4), 493-504.

Oerlemans, L., Meeus, M., \& Boekema, F. (2001) On the spatial embeddedness of innovation networks: an exploration of the proximity effect. Tijdschrift voor economische en sociale geografie, 92(1), 60-75.

Pilyasov, A.N. (2011) New economic geography and its potential for studying the location of Russias productive forces. Regional studies, 1, 3-31. (In Russ.)

Qiu, J., Liu, W., \& Ning, N. (2020) Evolution of Regional Innovation with Spatial Knowledge Spillovers: Convergence or Divergence? Networks \& spatial economics, 20(1), 179-208.

Rodoman, B.B. (2012) Territorial areas and networks. Smolensk, 277. (In Russ.)

Tatarkin, A.I. (2005) Socio-economic status of the middle region of Russia. Regional economy, 2, 5-22. (In Russ.)

Wang, H., Pan, C., Wang, Q., \& Zhou, P. (2020) Assessing sustainability performance of global supply chains: An input-output modeling approach. European journal of operational research, 285(1), 393-404.

Weber, A. (1909) Uberden Standortder Industrien. Tubingen, 124.

Wiberg, M. (2019) Capital controls and the location of industry. World economy, 43(4), 871-891.

Zemtsov, S.P., \& Baburin, V.L. (2016) Does economic-geographical position affect innovation processes in Russian regions? Geography, environment, sustainability, 9(4), 14-32.

Zhao, X., \& Fan, L. (2019) Spatial distribution characteristics and convergence of China's regional energy intensity: An industrial transfer perspective. Journal of cleaner production, 233, 903-917.

Тота, G., Kincses, A., \& Nagy, Z. (2014). The European spatial structure. LAP LAMBERT Academic Publishing, 285. 


\section{Information about the authors}

Victoria V. Akberdina - Dr. Sc. (Econ.), corresponding member of the RAS, Deputy Director Institute of Economics of the Ural Branch of the Russian Academy of Sciences, Head of Regional Industrial Policy and Economic Security Dept. (29 Moskovskaya St., Yekaterinburg, 620014, Russia); e-mail:akb_vic@mail.ru

Alena S. Sergeeva - postgraduate student, Institute of Economics of the Ural Branch of the Russian Academy of Sciences (29 Moskovskaya str., Yekaterinburg, 620014, Russia); e-mail: zabr0dina@mail.ru

ARTICLE INFO: received December 15, 2019; accepted February 12, 2020

\section{Информация об авторах}

Акбердина Виктория Викторовна - доктор экономических наук, член-корреспондент РАН, врио заместителя директора Института экономики Уральского отделения РАН, заведующий отделом региональной промышленной политики и экономической безопасности, профессор Уральского федерального университета (620014, Россия, г. Екатеринбург, ул. Московская, 29); e-mail: akb_vic@mail.ru

Сергеева Алёна Сергеевна - аспирант Института экономики Уральского отделения РАН (620014, Россия, г. Екатеринбург, ул. Московская, 29

ИНФОРМАЦИЯ О СТАТЬЕ: дата поступления 15 декабря 2019 г.; дата принятия к печати 12 февраля 2020 г. 